\title{
The influence of the manufacturing process of rotary files on the shaping of L-shaped canals
}

\section{Wpływ procesu wytwarzania rotacyjnych pilników endodontycznych na opracowanie kanału w kształcie litery L}

\author{
Mateusz Radwański ${ }^{A-D, F}$, Michał Łęski ${ }^{\mathrm{A}, \mathrm{E}, \mathrm{F}}$, Halina Pawlicka ${ }^{\mathrm{E}, \mathrm{F}}$ \\ Department of Endodontics, Medical University of Lodz, Poland \\ A - research concept and design; B - collection and/or assembly of data; $C$ - data analysis and interpretation; \\ $D$ - writing the article; $E$ - critical revision of the article; $F$ - final approval of the article
}

Address for correspondence

Mateusz Radwański

E-mail: mateusz.radwanski@gmail.com

Funding sources

The study was funded by Medical University of Lodz, Poland (502-03/2-044-02/502-24-069-17).

Conflict of interest

None declared

Received on August 16, 2018

Reviewed on September 2, 2018

Accepted on September 17, 2018

Published online on November 13, 2018

Cite as

Radwański M, Łęski M, Pawlicka H. The influence of the manufacturing process of rotary files on the shaping of $L$-shaped canals [published online as ahead of print on November 13, 2018]. Dent Med Probl. 2018;55(4):389-394. doi:10.17219/dmp/95201

DOI

10.17219/dmp/95201

Copyright

() 2018 by Wroclaw Medical University

and Polish Dental Society

This is an article distributed under the terms of the

Creative Commons Attribution Non-Commercial License

(http://creativecommons.org/licenses/by-nc-nd/4.0/)

\begin{abstract}
Background. The nickel-titanium alloy used in the production of nickel-titanium files contains approx. $56 \%$ nickel and 44\% titanium by weight. To improve the properties of nickel-titanium files, the manufacturers introduce some innovations in the production process. Their purpose is primarily to decrease the stiffness of the instruments while increasing the resistance to cyclic fatigue, which reduces the risk of file separation. One of the most popular processes is the heat treatment of the nickel-titanium alloy.

Objectives. The aim of the research was to determine the influence of the manufacturing process of rotary files on the shaping of L-shaped canals.
\end{abstract}

Material and methods. Fifty L-shaped resin canals were instrumented (10/group) with ProTaper Universa ${ }^{\circledR}$, ProTaper Next ${ }^{\circledR}$, Hyflex $\mathrm{CM}^{\circledR}$, Hyflex EDM ${ }^{\circledR}$, or WaveOne Gold ${ }^{\circledR}$ files, with the same apical size of 25. Each L-shaped resin canal was photographed both before and after instrumentation. Differences between the change of the working length and apical transportation were analyzed statistically.

Results. The smallest mean loss of the working length was observed after instrumentation with Hyflex CM files. Statistically significant differences in the working length were found between ProTaper Universal and Hyflex CM ( $p=0.0032)$, ProTaper Universal and Hyflex EDM ( $p=0.021)$, and ProTaper Universal and WaveOne Gold ( $p=0.0112$ ) files. The lowest apical transportation was noted in the case of WaveOne Gold files. In terms of apical transportation, statistically significant differences were observed between ProTaper Universal and WaveOne Gold files ( $p=0.0254)$. Shaping L- shaped canals with the ProTaper Universal file system resulted in the greatest changes in the working length $(x=0.35 \mathrm{~mm})$ and apical transportation $(x=0.034 \mathrm{~mm})$.

Conclusions. The study, with its limitations, shows that in the files whose nickel-titanium alloy was subjected to a thermal treatment process, a smaller loss of the working length and lower values of apical transportation were observed.

Key words: nickel-titanium rotary files, canal shaping, resin blocks

Słowa kluczowe: niklowo-tytanowe rotacyjne pilniki endodontyczne, opracowanie kanału, bloki żywicowe 


\section{Introduction}

The nickel-titanium alloy (nitinol) used in the production of nickel-titanium files contains approx. 56\% nickel and $44 \%$ titanium by weight, with the atomic ratio of the elements being the same (equiatomic). In some nickel-titanium alloys, a small percentage $(<2 \%$ by weight) of nickel is converted to cobalt. ${ }^{1}$ Due to the ability to change the type of atomic bonds by the elements included in the alloy, the mechanical properties and its crystal structure change. These changes occur under temperature and/or stress. In dentistry, 2 characteristics of the nickel-titanium alloy are important, referred to as the shape memory effect and pseudoelasticity. ${ }^{1}$

To improve the properties of nickel-titanium files, the manufacturers introduce some innovations in the production process. Their purpose is primarily to decrease the stiffness of the instruments, while increasing the resistance to cyclic fatigue, which reduces the risk of file separation. One of the most popular processes is the heat treatment of the nickel-titanium alloy.

The heat treatment of nickel-titanium instruments affects the temperature of phase transformations, thus determining the nickel-titanium alloy phases present in the file at room temperature. ${ }^{2,3}$ This process can improve the alloy properties if it is carried out in specific temperatures. Zinelis et al. showed that the heat treatment up to $430-440^{\circ} \mathrm{C}$ gradually increased the resistance of files to cyclic fatigue, and machining above these temperatures adversely affected the file properties. ${ }^{4}$

In determining the structure of nitinol, it is common to compare the end temperature of austenitic transformation (the $\mathrm{A}_{\mathrm{f}}$ temperature) to the reference temperature. The reference temperature is usually defined as room temperature $\left(37^{\circ} \mathrm{C}\right)$. In the case when the $\mathrm{A}_{\mathrm{f}}$ temperature is lower than the reference temperature, the alloy at room temperature will be completely in the austenitic phase. The heat treatment process can raise the $\mathrm{A}_{\mathrm{f}}$ temperature $\left(45-50^{\circ} \mathrm{C}\right) .^{5}$ This means that at room temperature the alloy can be a mixture of the martensitic phase with the austenitic phase and/or the rhombohedrally distortion of the cubic austenitic phase (R-phase).

In 2017, a classification of nickel-titanium rotary files into 3 generations was proposed, taking the crystallographic structure and the thermal process as the criteria for classification. ${ }^{6}$

The $1^{\text {st }}$ generation includes files in the austenitic phase, with the $A_{f}$ temperature below the reference temperature $\left(\mathrm{A}_{\mathrm{f}}<37^{\circ} \mathrm{C}\right) .^{7-10}$ This group includes Endo Sequence ${ }^{\circledR}$ (Brasseler, Savannah, USA) with $\mathrm{A}_{\mathrm{f}}=31.13^{\circ} \mathrm{C}$, ${ }^{9}$ ProFile $^{\circledR}$ (Dentsply Tulsa Dental, Tulsa, USA) with $\mathrm{A}_{\mathrm{f}}=16.98^{\circ} \mathrm{C}^{9}$ and ProTaper Universal ${ }^{\circledR}$ (Dentsply Tulsa Dental) with $\mathrm{A}_{\mathrm{f}}=17^{\circ} \mathrm{C} .^{5}$

The $2^{\text {nd }}$ generation includes files that contain a stable martensite phase under clinical conditions. The heat treatment process raises the $\mathrm{A}_{\mathrm{f}}$ temperature, producing a variable crystallographic percentage of martensite, $\mathrm{R}$-phase and/or austenite around room temperature. ${ }^{5,11}$ Depending on the thermodynamic processing of the alloy before or during production, this group includes nickeltitanium alloys referred to as M-Wire ${ }^{\circledR}, \mathrm{R}-$ phase $^{\circledR}$ and Controlled Memory ${ }^{\circledR}$ (CM-Wire).

M-Wire was introduced in 2007 by Dentsply Tulsa Dental Specialties and its production is related to the cycles of the heat treatment and annealing. ${ }^{12}$ This cyclic process aims to stabilize the crystalline structure of nitinol in a martensitic state at room temperature. ${ }^{13,14}$ Various analytical methods have confirmed that M-Wire contains austenite, martensite and $\mathrm{R}$-phase. The relative proportions depend on the processing conditions. The $\mathrm{A}_{\mathrm{f}}$ temperature of $\mathrm{M}$-Wire is about $45-50^{\circ} \mathrm{C} .^{5}$ The M-Wire instruments include Dentsply Tulsa Dental Specialties files: ProFile Vortex ${ }^{\circledR}\left(\mathrm{A}_{\mathrm{f}} \approx 50^{\circ} \mathrm{C}\right),{ }^{9}$ ProTaper $\operatorname{Next}^{\circledR}\left(\mathrm{A}_{\mathrm{f}} \approx 54^{\circ} \mathrm{C}\right),{ }^{15}$ PathFiles $^{\circledR}$, and WaveOne ${ }^{\circledR}$. This group also includes Re$\operatorname{ciproc}^{\circledR}$ (VDW, Munich, Germany).

Controlled Memory (DS Dental, Johnson City, USA) was introduced in 2010. The proprietary thermo-mechanical process aims to reduce stiffness and shape memory, raise the $\mathrm{A}_{\mathrm{f}}$ temperature to about $50^{\circ} \mathrm{C}$ and achieve stable martensite phase at body temperature. ${ }^{16}$ Testarelli et al. found that CM contains a lower percentage of nickel (52\% by weight). ${ }^{17}$ The CM instruments include Hyflex $\mathrm{CM}^{\circledR}$ (Coltene Whaledent, Cuyahoga Falls, USA) with $\mathrm{A}_{\mathrm{f}} \approx 57^{\circ} \mathrm{C}^{18}$ and Typhoon $\mathrm{CM}^{\circledR}$ (Clinican's Choice Dental Products, New Milford, USA) with $\mathrm{A}_{\mathrm{f}} \approx 55^{\circ} \mathrm{C} .{ }^{19}$ Studies confirm that in addition to austenite at a reference temperature, the instruments also contain martensite and R-phase. ${ }^{20}$

The $3^{\text {rd }}$ generation is nickel-titanium rotary instruments, whose alloys have been subjected to the heat treatment after machining. The new heating process after machining is aimed at minimizing defects that appeared while machining and modifying the structure of the crystalline phase. After the thermal cycle, the martensitic transformation of nitinol occurs in 2 stages (austeniteR-phase-martensite) instead of 1 (austenite-martensite). ${ }^{21}$

This group includes Dentsply Tulsa Dental Specialties: Vortex Blue ${ }^{\circledR}$, TRU Shape ${ }^{\circledR}$, ProTaper Gold ${ }^{\circledR}$, and WaveOne Gold $^{\circledR}$. The $3^{\text {rd }}$ generation also includes Hyflex EDM ${ }^{\circledR}$ (Coltene Whaledent), XP-endo Shaper ${ }^{\circledR}$ (FKG Dentaire, La Chaux-de-Fonds, Switzerland) and K3 XF ${ }^{\circledR}$ (SybronEndo, Orange, USA).

WaveOne Gold files are created in a unique heat treatment process, prior and after file manufacturing. In the first stage, nitinol is subjected to a special heat treatment under constant strain $(3-15 \mathrm{~kg})$ in the temperature range of about $410-440^{\circ} \mathrm{C}$. Then, after machining, the instrument is heat-treated once again at a temperature of $120-260^{\circ} \mathrm{C}$. The $\mathrm{A}_{\mathrm{f}}$ temperature is between $40^{\circ} \mathrm{C}$ and $60^{\circ} \mathrm{C} .{ }^{22}$

Hyflex EDM is manufactured using electrical discharging machining (EDM). Electrical discharging machining is a non-contact thermal erosion process used to treat 
materials with controlled electric discharges. Electric sparks cause local melting and partial evaporation of small portions of the material. After cutting, cleaning in an acid bath is carried out with the use of ultrasound. The instrument is subjected to the heat treatment at a temperature of $300-600^{\circ} \mathrm{C}$ before or after the cleaning process. ${ }^{23}$ The EDM files have $\mathrm{A}_{\mathrm{f}}>52^{\circ} \mathrm{C} .{ }^{24}$

The aim of the research was to determine the effect of the manufacturing process of rotary files on the shaping of L-shaped canals.

\section{Material and methods}

The following nickel-titanium rotary files were used in the study: ProTaper Universal (group I), ProTaper Next (group II), Hyflex CM (group III), Hyflex EDM (group IV), and WaveOne Gold (group V).

Fifty blocks with L-shaped canals (Endo-Training Blocks ${ }^{\circledR} 02$ taper, REFA 0177; Dentsply Maillefer, Ballaigues, Switzerland) were used in the laboratory tests. The canals were characterized by the following parameters: the working length $-16 \mathrm{~mm}$, apex size -15 and conicity $-2 \%$.

The blocks were randomly divided into 5 groups, 10 in each. Before starting work with the rotary files, the working length of the canal and the apical patency were confirmed using K-file 15 (VDW). The working length was verified with an endodontic ruler and a rubber stop. The canals were filled with black ink. Next, the glide path and pre-flaring were performed using PathFile ${ }^{\circledR}$ (Dentsply Maillefer).

The canals were shaped with the nickel-titanium rotary files in each group, respecting the sequence, speed and torque recommended by the manufacturer. The sequence of the files is shown in Table 1. The canals were instrumented using the TECNIKA ${ }^{\circledR}$ micromotor (Dentsply Maillefer) in groups I-IV and the WaveOne Endo Motor $^{\circledR}$ micromotor (Dentsply Maillefer) in group V. Each file was used once and the canals were prepared to an apical size of 25. Between using particular files, the canals were rinsed with $0.9 \%$ saline. Glycerin was used as a lubricant and apical patency was controlled using C-pilot 10 (VDW).
The resin blocks were fixed in a constant position and photographed before and after preparation. Photographs were saved as JPEG files and were superimposed using the GIMP 2.6 ${ }^{\circledR}$ program (https://www.gimp.org/downloads/). The change in the working length and apical transportation were evaluated.

The working length after shaping the canals was measured with an endodontic ruler, using a magnifying glass with an accuracy of $0.25 \mathrm{~mm}$. There was a change in length in relation to the previously confirmed length of the canal $(16 \mathrm{~mm})$. Apical transportation, i.e., the shift of the apex to the outer or inner side, was assessed by determining the difference between the average amount of the material removed from the external wall of the canal and the average amount of the material removed from the internal wall ( 1 measuring point

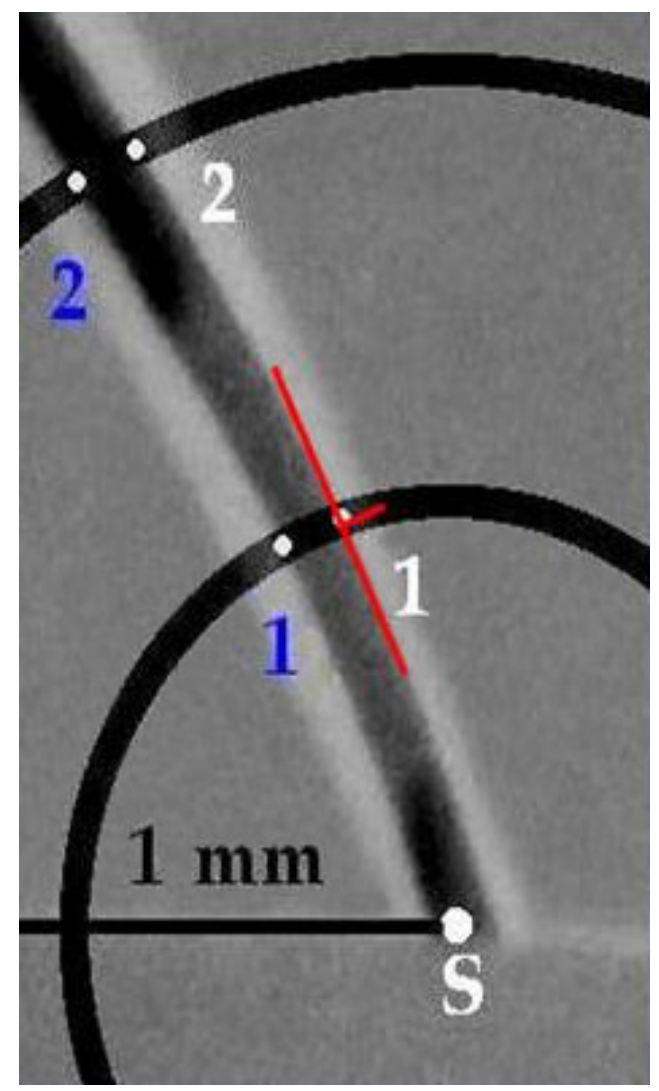

Fig. 1. Measurement of apical transportation

Table 1. Sequence of files, speed and torque

\begin{tabular}{|c|c|c|c|c|c|}
\hline $\begin{array}{l}\text { Sequence, speed } \\
\text { and torque }\end{array}$ & $\begin{array}{c}\text { ProTaper Universal } \\
\text { group I }\end{array}$ & $\begin{array}{l}\text { ProTaper Next } \\
\text { group II }\end{array}$ & $\begin{array}{l}\text { Hyflex CM } \\
\text { group III }\end{array}$ & $\begin{array}{l}\text { Hyflex EDM } \\
\text { group IV }\end{array}$ & $\begin{array}{l}\text { WaveOne Gold } \\
\text { group V }\end{array}$ \\
\hline Sequence of files & $\begin{array}{l}\text { Sx (19/.04) orifice preparation } \\
\text { S1 }(18 / .02) 2 / 3 \mathrm{WL}(11 \mathrm{~mm}) \\
\text { S2 }(20 / .04) 2 / 3 \mathrm{WL}(11 \mathrm{~mm}) \\
\text { F1 }(20 / .07) 16 \mathrm{~mm} \\
\text { *F2 (25/.08) } 16 \mathrm{~mm}\end{array}$ & $\begin{array}{l}X 1(17 / .04) 16 \mathrm{~mm} \\
* X 2(25 / .06) 16 \mathrm{~mm}\end{array}$ & $\begin{array}{l}\text { 25/.08 1/3 WL (5 mm) } \\
\text { 20/.04 16 mm } \\
{ }^{*} 25 / .0416 \mathrm{~mm}\end{array}$ & *25/.08 (Hyflex One File) 16 mm & *25/.07 (Primary) $16 \mathrm{~mm}$ \\
\hline Speed [rpm] & 300 & 300 & 500 & 500 & reciprocating motion \\
\hline Torque [Ncm] & 2.5 & 2.5 & 2.5 & 2.5 & - \\
\hline
\end{tabular}

Glide path: path files - P1 (13/.02), P2 (16/.02); WL = 16 mm; WL - working length; Sx, S1, S2, F1, F2, X1, X2 - files used in the sequence;

* files used as the last. 
for the outer and inner canal walls, respectively) (Fig. 1). If the result was negative, the apex moved toward the inner wall of the canal, and thus a positive result meant transport to the outer wall.

The results obtained were subjected to statistical analysis. For variables, average measurements were calculated: the arithmetic mean (x), the median (Me) and the scattering pattern - standard deviation (SD). Then, the compatibility of distributions of the variables analyzed with the normal distribution was checked using the Shapiro-Wilk test. Due to the deviation of distributions from normal distributions, the nonparametric Kruskal-Wallis test was performed to compare many means. The Dunnett multiple comparison test was used to compare the means with post-hoc pairs. The analysis was carried out using the STATISTICA v.12 PL ${ }^{\circledR}$ program (StatSoft Sp. z o.o., Kraków, Poland). The level of significance was set at $p<0.05$.

\section{Results}

\section{Changes in working length}

The mean loss of the working length is shown in Fig. 2.

The largest loss of length was found after shaping with ProTaper Universal file $(0.35 \pm 0.17 \mathrm{~mm})$, followed by ProTaper Next $(0.25 \pm 0.17 \mathrm{~mm})$, Hyflex EDM $(0.175$ $\pm 0.17 \mathrm{~mm})$, WaveOne Gold $(0.15 \pm 0.17 \mathrm{~mm})$, and Hyflex CM $(0.125 \pm 0.18 \mathrm{~mm})$.

The pairwise comparison showed a statistically significant difference in the change in the canal working length between ProTaper Universal and Hyflex CM $(p=0.0032)$, ProTaper Universal and Hyflex EDM $(p=0.021)$, and ProTaper Universal and WaveOne Gold $(p=0.0112)$ files. Thus, the change in the working length of the canal was significantly lower when using Hyflex CM, Hyflex EDM and WaveOne Gold files as compared to ProTaper Universal.

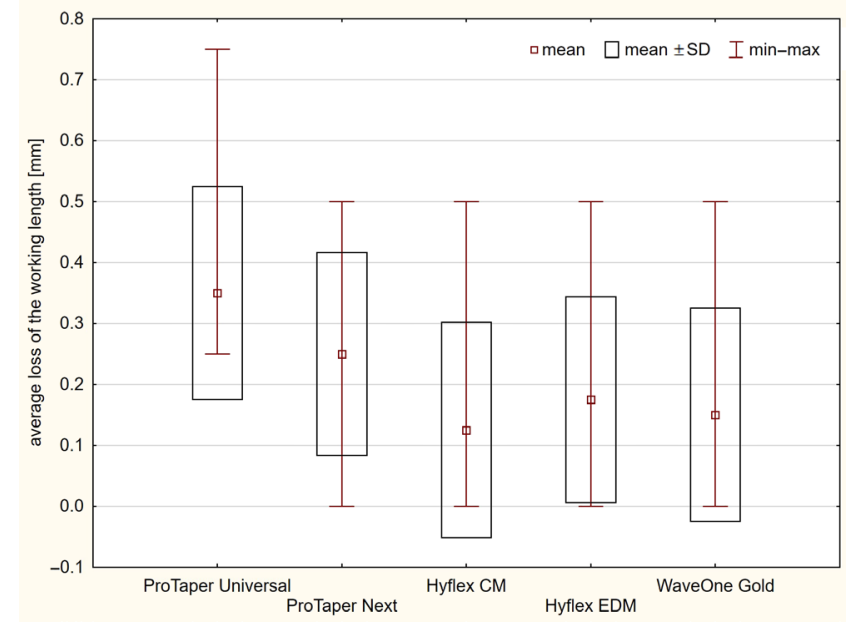

Fig. 2. Average change of the working length [mm] SD - standard deviation.

\section{Apical transportation}

The mean apical transportation is shown in Fig. 3.

The mean apical transportation for WaveOne Gold was $0.001 \pm 0.024 \mathrm{~mm}$, for Hyflex CM $-0.014 \pm 0.027 \mathrm{~mm}$, for Hyflex EDM $-0.017 \pm 0.034 \mathrm{~mm}$, for ProTaper Next $-0.022 \pm 0.030 \mathrm{~mm}$, and for ProTaper Universal -0.034 $\pm 0.017 \mathrm{~mm}$.

Analyzing the results of transport for individual groups, in WaveOne Gold files, the apex was transported to the outer wall in 6 cases and to the inner wall in 4 cases. In the Hyflex CM and Hyflex EDM groups, the transport was found on the external wall in 8 cases and on the internal wall in 2 cases. For the ProTaper Next group, the apex was transported to the outer wall in 7 cases, and in 3 cases to the inner wall. In 9 ProTaper Universal cases, the apex was transported to the external wall and in 1 case to the internal wall.

The comparison of apical transportation in pairs showed a statistically significant difference only between ProTaper Universal and WaveOne Gold at $p=0.0245$. The value of apical transportation was significantly higher in the case of canals shaped with ProTaper Universal files as compared to WaveOne Gold ones.

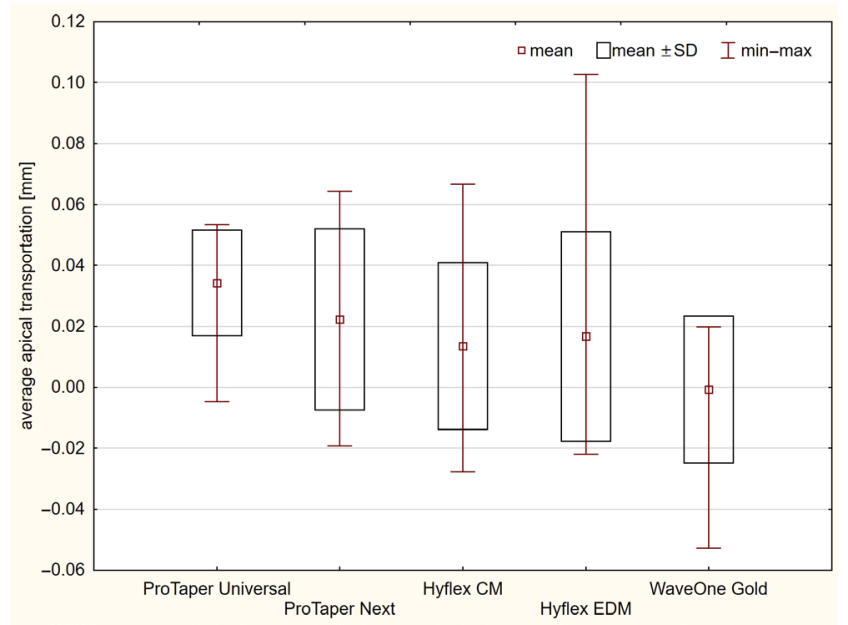

Fig. 3. Average apical transportation [mm]

\section{Discussion}

In the studies, 2 models are commonly used for the comparison of root canal shaping: resin blocks or roots of extracted teeth. ${ }^{25-27}$ In the present study, the authors decided to use the blocks to evaluate the parameters. In these blocks, canals have precisely defined parameters, such as shape, size, conicity, and degree of curvature. Therefore, the experimental conditions are repeatable, and the only variables are the method of canal preparation and the experience of the operator. ${ }^{26}$ Due to transparency, the blocks can be easily compared, which makes the measurements and calculations precise and accessible. 
However, they do not reflect the anatomy of natural teeth and the analysis of the parameters studied takes place in 2 dimensions. ${ }^{27}$ Another disadvantage is the fact that the test blocks are made of resin, i.e., a material with mechanical parameters completely different from those of dentin. According to González Sánchez et al., the difference in hardness between dentin and resin can affect the results of clinical work. ${ }^{25}$ It should also be emphasized that during operations with rotary files, heat is generated, which may contribute to the softening of the resin material, thus leading to inefficient shaping. ${ }^{25,26}$ In conclusion, resin blocks are selected for testing, as the same conditions are provided for each instrument assessed. In the case of human teeth, due to the complex anatomy of root canals, it is difficult or impossible to achieve the same experimental settings. The results of tests on resin blocks can therefore be compared, although they cannot be directly transferred to the evaluation of files in clinical situations.

To evaluate the effectiveness of canal preparation with endodontic files, the study compared the loss of the working length and apical transportation.

When comparing the shaping ability, it is important to maintain the same apical size. ${ }^{28}$ In all the groups examined, the last used file had the same size on the tip -25 . The files differed only in conicity. In the case of groups I (ProTaper Universal) and IV (Hyflex EDM), the conicity was $8 \%(0.08)$. The last file used in group $\mathrm{V}$ (WaveOne Gold) was characterized by conicity of $7 \%(0.07)$, in group II (ProTaper Next) - 6\% (0.06) and in group III (Hyflex $\mathrm{CM})-4 \%(0.04)$. During the research, none of the instruments was broken.

Modern rotary files are made of the nickel-titanium alloy, which over the years has been subjected to numerous modifications, both in the process of mechanical manufacturing and final machining. Manufacturers, through the introduction of modern technologies, influence the parameters of the traditional nickel-titanium alloy. The changes introduced are primarily aimed at reducing the stiffness of nickel-titanium files with an increase in their resistance to cyclic fatigue.

In the literature, there are more and more studies comparing the shaping of canals by means of nickel-titanium files subjected to various heat treatment processes. ${ }^{29,30}$

$\mathrm{Gu}$ et al., in their study comparing Twisted Files ${ }^{\circledR}$ (SybronEndo) (R-phase), WaveOne (M-Wire), Hyflex CM, and V Taper $2 \mathrm{H}^{\circledR}$ (SS White Dental Inc., Lakewood, USA) (CM-Wire), showed that the highest apical transportation of S-shaped canals was observed in the Twisted Files (TF) group. ${ }^{29}$ It should be noted that the authors chose files classified into the same, $2^{\text {nd }}$ generation. According to the study, the higher apical transportation is the result of the lower transformation temperature $\left(\mathrm{A}_{\mathrm{f}}\right)$ for $\mathrm{TF}\left(\mathrm{A}_{\mathrm{f}}<20^{\circ} \mathrm{C}\right)$ in comparison with other files $\left(\mathrm{A}_{\mathrm{f}} \approx 50^{\circ} \mathrm{C}\right)$. Twisted Files are stiffer and contribute to greater changes in the apical region. ${ }^{29}$
The study of Liu et al. compared the shaping ability of ProTaper Universal ( $1^{\text {st }}$ generation), ProTaper Next (M-Wire, $2^{\text {nd }}$ generation), Hyflex CM (CM-Wire, $2^{\text {nd }}$ generation), Reciproc (M-Wire, $2^{\text {nd }}$ generation), and TF Adaptive ${ }^{\circledR}$ (SybronEndo) $\left(2^{\text {nd }}\right.$ generation - the newly introduced TF Adaptive system uses en existing file set called Twisted Files in conjunction with the new Elements Motion featuring Adaptive Motion) in L-shaped canals. The results showed that less apical transportation was observed in the case of files whose nickel-titanium alloy was subjected to the thermal treatment process. ${ }^{30}$

In the present study, files from all generations included in the classification were used. The $1^{\text {st }}$ one comprises ProTaper Universal, the $2^{\text {nd }}-$ ProTaper Next (M-Wire) and Hyflex CM (CM), and the $3^{\text {rd }}-$ Hyflex EDM and WaveOne Gold. Lower values of apical transportation and loss of the working length were observed after instrumentation with files that are characterized by lower stiffness (the $2^{\text {nd }}$ and $3^{\text {rd }}$ generation). ProTaper Universal, with $\mathrm{A}_{\mathrm{f}}=17^{\circ} \mathrm{C}$, at room temperature $\left(37^{\circ} \mathrm{C}\right)$ are in the austenitic phase and are characterized by greater stiffness. Other files, due to $A_{f}>37^{\circ} \mathrm{C}$, are characterized by lower stiffness. In the study, files whose nickel-titanium alloy was subjected to the thermal treatment process better maintained the original course of the canal and contributed to a smaller loss of the working length and apical transportation.

\section{Conclusions}

The study, with its limitations, shows that in the files whose nickel-titanium alloy was subjected to the thermal treatment process, a smaller loss of the working length and lower values of apical transportation were observed.

\section{References}

1. Thompson SA. An overview of nickel-titanium alloys used in dentistry. Int Endod J. 2000;33:297-310.

2. Kuhn G, Jordan L. Fatigue and mechanical properties of nickeltitanium endodontic instruments. J Endod. 2002;28:716-720.

3. Kuhn G, Tavernier B, Jordan L. Influence of structure on nickeltitanium endodontic instruments failure. J Endod. 2001;27:516-520.

4. Zinelis S, Darabara M, Takase T, Ogane K, Papadimitriou GD. The effect of thermal treatment on the resistance of nickel-titanium rotary files in cyclic fatigue. Oral Surg Oral Med Oral Pathol Oral Radiol Endod. 2007;103:843-847.

5. Alapati SB, Brantley WA, lijima M, et al. Micro-XRD and temperature-modulated DSC investigation of nickel-titanium rotary endodontic instruments. Dent Mater. 2009;25:1221-1229.

6. Walid N. Review and classification of heat treatment procedures of NiTi instruments and its implication on files fatigue. J Dent Sci. 2017;2:1-19.

7. Brantley WA, Svec TA, lijima M, Powers JM, Grentzer TH. Differential scanning calorimetric studies of nickel titanium rotary endodontic instruments. Analysis. 2002;28:774-778.

8. Hou XM, Yahata Y, Hayashi Y, Ebihara A, Hanawa T, Suda H. Phase transformation behaviour and bending property of twisted nickeltitanium endodontic instruments. Int Endod J. 2011;44:253-258.

9. Shen Y, Zhou HM, Zheng YF, Campbell L, Peng B, Haapasalo M. Metallurgical characterization of controlled memory wire nickel-titanium rotary instruments. J Endod. 2011;37:1566-1571. 
10. Zhou HM, Shen Y, Zheng W, Li L, Zheng YF, Haapasalo M. Mechanical properties of controlled memory and superelastic nickeltitanium wires used in the manufacture of rotary endodontic instruments. J Endod. 2012;38:1535-1540.

11. Shen Y, Zhou HM, Zheng YF, Peng B, Haapasalo M. Current challenges and concepts of the thermomechanical treatment of nickeltitanium instruments. J Endod. 2013;39:163-172.

12. Kell T, Azarpazhooh A, Peters OA, El-Mowafy O, Tompson B, Basrani B. Torsional profiles of new and used 20/06 GT Series $X$ and GT rotary endodontic instruments. J Endod. 2009;35:1278-1281.

13. Berendt C. Method of preparing nitinol for use in manufacturing instruments with improved fatigue resistance. United States Patent \& Trademark Office, United States Patent Application 20070072147, March 29, 2007.

14. Ye J, Gao Y. Metallurgical characterization of M-Wire nickel-titanium shape memory alloy used for endodontic rotary instruments during low-cycle fatigue. J Endod. 2012;38:105-107.

15. Aminsobhani M, Khalatbari MS, Meraji N, Ghorbanzadeh A, Sadri E. Evaluation of the fractured surface of five endodontic rotary instruments: A metallurgical study. Iran Endod J. 2016;11:286-292.

16. de Arruda Santos L, de Azevedo Bahia MG, de Las Casas EB, Buono VTL. Comparison of the mechanical behavior between controlled memory and superelastic nickel-titanium files via finite element analysis. J Endod. 2013;39:1444-1447.

17. Testarelli $\mathrm{L}$, Plotino G, Al-Sudani $\mathrm{D}$, et al. Bending properties of a new nickel-titanium alloy with a lower percent by weight of nickel. J Endod. 2011;37:1293-1295.

18. Shen Y, Coil JM, Zhou H, Zheng Y, Haapasalo M. HyFlex nickel-titanium rotary instruments after clinical use: Metallurgical properties. Int Endod J. 2013;46:720-729.

19. De Vasconcelos RA, Murphy S, Carvalho CAT, Govindjee RG, Govindjee $S$, Peters OA. Evidence for reduced fatigue resistance of contemporary rotary instruments exposed to body temperature. J Endod. 2016;42:782-787.

20. Pereira ESJ, Peixoto IFC, Viana ACD, et al. Physical and mechanical properties of a thermomechanically treated NiTi wire used in the manufacture of rotary endodontic instruments. Int Endod J. 2012;45:469-474.

21. Otsuka K, Ren X. Physical metallurgy of Ti-Ni-based shape memory alloys. Prog Mater Sci. 2005;50:511-678.

22. Brantley WA, Alapati SB. Heat treatment of dental alloys: A review. In: Pardhi Y, ed. Metallurgy - Advances in Materials and Processes. London, UK: IntechOpen; 2012:11-15.

23. Pirani $C$, lacono $F$, Generali $L$, et al. HyFlex EDM: Superficial features, metallurgical analysis and fatigue resistance of innovative electro discharge machined NiTi rotary instruments. Int Endod J. 2016;49:483-493.

24. Iacono F, Pirani C, Generali L, et al. Structural analysis of HyFlex EDM instruments. Int Endod J. 2017;50:303-313.

25. González Sánchez JA, Duran-Sindreu F, de Noé S, Mercadé M, Roig $M$. Centring ability and apical transportation after overinstrumentation with ProTaper Universal and ProFile Vortex instruments. Int Endod J. 2012;45:542-551.

26. Yoo YS, Cho YB. A comparison of the shaping ability of reciprocating NiTi instruments in simulated curved canals. Restor Dent Endod. 2012;37:220-227.

27. Zmener O, Banegas G. Comparison of three instrumentation techniques in the preparation of simulated curved root canals. Int Endod J. 1996:29:315-319.

28. Bergmans L, Van Cleynenbreugel J, Beullens $M$, Wevers M, Van Meerbeek B, Lambrechts P. Progressive versus constant tapered shaft design using NiTi rotary instruments. Int Endod J. 2003;36:288-295.

29. Gu Y, Kum KY, Perinpanayagam $H$, et al. Various heat-treated nickel-titanium rotary instruments evaluated in S-shaped simulated resin canals. J Dent Sci. 2017;12:14-20.

30. Liu Y, Qiu N, Xue M, Wang C, Yu X. Comparison of shaping ability of five nickel-titanium rotary instruments in simulated curved canals. J Dent Oral Health. 2017;3. https://scientonline.org/openaccess/comparison-of-shaping-ability-of-five-nickel-titaniumrotary-instruments-in-simulated-curved-canals.pdf 